\title{
Aplikasi Diagnosa Dini Penyakit Tuberculosis Dengan Menggunakan Metode Certainty Factor
}

\author{
Trio Alfianto ${ }^{1}$, Benisius ${ }^{2}$ \\ Fakultas Teknik dan Ilmu Komputer, Program Studi Teknik Informatika \\ Universitas Kristen Krida Wacana \\ 1trio.2014tin035@ civitas.ukrida.ac.id, 2ehba@ukrida.ac.id
}

Diterima: 21 Agustus 2018 | Diperbaiki: 14 September 2018 | Disetujui: 20 September 2018

\begin{abstract}
Abstrak -- Tuberkulosis atau TB merupakan salah satu permasalahan kesehatan terbesar dan juga penyebab kematian kesembilan di seluruh dunia serta penyebab utama dari satu infectious Agents yang merupakan bahan pencemar yang dapat menyebabkan ganggunan kesehatan manusia. Indonesia merupakan salah satu dari lima negara dengan jumlah terbesar kasus insiden TB pada tahun 2016 bersama India, Cina, Filipina dan Pakistan. Dalam bidang ilmu komputer, pendekatan sistem pakar dapat diterapkan untuk membangun sebuah sistem yang dapat mendiagnosa suatu penyakit berdasarkan gejala-gejala umum yang ditimbulkannya. Permasalah terkait aspek ketidakpastian dari jawaban user yang dapat berdampak pada hasil diagnosa dapat diatasi dengan menerapkan metode certainty factor $(C F)$. Penelitian ini bertujuan mengembangkan suatu aplikasi sistem pakar diagnosa dini penyakit tuberkulosis berbasis android. Dengan memanfaatkan keunggulan aplikasi mobile yang dapat diunduh hanya melalui smartphone, aplikasi ini diharapkan dapat memudahkan masyarakat untuk mengetahui tingkat resiko terkena penyakit tuberkulosis sehingga olehnya upaya penanggulangan dini dapat segera dilakukan. Hasil penelitian menunjukkan bahwa metode certainty factor dapat digunakan untuk mengembangkan sebuah sistem pakar yang dapat digunakan untuk mendiagnosa penyakit tuberkulosis paru dan tuberkulosis kelenjar dengan tingkat kesalahan yang rendah.
\end{abstract}

Kata Kunci: tuberkulosis, android, certainty factor, tuberkulosis paru, tuberkulosis kelenjar

\section{PENDAHULUAN}

Tuberkulosis adalah penyakit yang disebabkan oleh bakteri mycobacterium tuberculosis. Bakteri tersebut dapat menyerang berbagai bagian tubuh manusia seperti ginjal, tulang, otak dan paru-paru serta bagian tubuh lainya. Paruparu merupakan bagian organ tubuh manusia yang paling rentan penyakit tuberkulosis [1]. Tuberkulosis merupakan salah satu permasalahan kesehatan terbesar dan juga penyebab kematian kesembilan di dunia serta penyebab utama infectious agents yang merupakan bahan pencemar yang dapat menyebabkan gangguan kesehatan manusia. Terdapat lima negara dengan kasus insiden tuberkulosis, kelima negara yang menonjol memiliki jumlah terbesar kasus insiden pada 2016 adalah (dalam urutan menurun) India, Indonesia, Cina, Filipina dan Pakistan [2].

Di Indonesia pada 2016 ditemukan jumlah kasus tuberkulosis sebanyak 351.893 kasus. Angka ini meningkat bila dibandingkan semua kasus tuberkulosis yang ditemukan pada 2015 yakni sebesar 330.729 kasus. Jumlah kasus tertinggi yang dilaporkan terdapat di provinsi dengan jumlah penduduk yang besar yaitu Jawa Barat, Jawa Timur dan Jawa Tengah. Kasus tuberkulosis di tiga provinsi tersebut sebesar 44\% dari jumlah seluruh kasus baru di Indonesia [3].

Salah satu faktor risiko terjadinya tuberkulosis di Indonesia adalah masih banyak masyarakat yang belum memiliki hunian yang memenuhi standar kesehatan [4]. Tempat tinggal masyarakat yang berada di lingkungan padat penduduk adalah faktor lain yang menyebabkan berbagai macam bakteri muncul sehingga dapat menyerang masyarakat sekitar. Faktor lainnya adalah masih kurangnya pengetahuan tentang perilaku hidup sehat serta belum adanya pembinaan terhadap penyakit tuberkulosis sendiri kepada masyarakat dari dinas kesehatan setempat [5]. Sebagian masyarakat juga masih mengganggap jika batuk selama berbulan-bulan merupakan batuk biasa. Padahal apabila dicermati batuk dalam jangka waktu yang panjang merupakan salah satu gejala penyakit tuberkulosis. Pada umumnya masyarakat baru akan memeriksakan penyakitnya ketika sudah parah. Kurangnya fasilitas yang memadai dan dokter ahli yang terbatas hingga kurangnya pengetahuan masyarakat mengenai penyakit tuberkulosis seringkali membuat diagnosis tuberkulosis terlambat sehingga dapat mengancam kesehatan masyarakat [6].

Dalam bidang ilmu komputer, pendekatan sistem pakar dapat diterapkan untuk membangun sebuah sistem yang dapat mendiagnosa suatu penyakit berdasarkan gejalagejala umum yang ditimbulkannya. Permasalah terkait aspek ketidakpastian dari jawaban user yang dapat berdampak pada hasil diagnosa dapat diatasi dengan menerapkan metode certainty factor $(C F)$.

Penelitian ini bertujuan mengembangkan suatu aplikasi sistem pakar diagnosa dini penyakit tuberkulosis berbasis android. Dengan memanfaatkan keunggulan aplikasi mobile yang dapat diunduh hanya melalui smartphone, aplikasi ini diharapkan dapat memudahkan masyarakat untuk mengetahui tingkat resiko terkena penyakit tuberkulosis sehingga olehnya upaya penanggulangan dini dapat segera dilakukan.

\section{KONSEP DASAR}

\section{A. Sistem Pakar}

Sistem pakar (expert system) adalah cabang dari kecerdasan buatan atau Artificial Intelligence (AI) dan juga merupakan bidang ilmu yang muncul dengan seiring 
perkembangan ilmu komputer. Sistem ini merupakan sistem komputer yang bisa menyamai atau meniru kemampuan seorang pakar, sistem ini bekerja untuk mengadopsi pengetahuan manusia ke komputer yang menggabungkan dasar pengetahuan untuk menggantikan fungsu seorang pakar dalam menyelesaikan suatu masalah [7].

\section{B. Tuberkulosis}

Tuberkulosis atau TB adalah suatu penyakit infeksi menular yang disebabkan bakteri Mycobacterium Tuberculosis, yang dapat menyerang berbagai organ, terutama paru-paru. Penyakit ini bila tidak diobati atau pengobatannya tidak tuntas dapat menimbulkan komplikasi berbahaya hingga kematian. Tuberkulosis diperkirakan sudah ada di dunia sejak 5000 tahun sebelum Masehi, namun kemajuan dalam penemuan dan pengendalian penyakit tuberkulosis baru terjadi dalam dua abad terakhir [8].

Penyakit tuberkulosis sering menyerang bagian paru-paru (Pulmonary Tuberculosis) saja seperti anggapan kebanyakan orang, selain menyerang paru ada juga yang dapat menyerang organ tubuh lain (tuberkulosis ekstra paru), beberapa jenis tuberkulosis ekstra paru seperti otak (Miningitis Tuberculosis), kalenjar getah bening (Lymphedenopathy Tuberculosis), bagian terluar dari paruparu (Pleurisy Tuberculosis), kulit (Miliary Tuberculosis), tulang (Spine of Tuberculosis), payudara (Mastitis Tuberkulosis) dan saluran urogenital (Urogenital Tuberculosis). Lama tidaknya pengobatan bagi penderita Tuberculosis tergantung pada jenis Tuberculosis yang diderita, parah tidaknya infeksi yang terjadi dan lama penanganan penderita dari awal terinfeksi hingga waktu pengobatan. Semakin cepat seseorang sadar terdiagnosa penyakit Tuberculosis dan melakukan pemeriksaan, maka proses penyembuhan yang dilakukan dimungkinkan akan semakin cepat dan sebaliknya [9].

\section{Certainty Factor}

Konsep certainty factor diusulkan untuk mengakomodasi ketidakpastian seorang ahli yang sering berpikir untuk menganalisa informasi dengan frasa seperti "mungkin", "kemungkinan besar", "hampir pasti" dan sebagainya. Metode pemilihan certainty factor cocok untuk sistem pakar dalam penelitian ini, karena pada dasarnya metode CF diasumsikan sebagai tingkat kepercayaan ahli untuk data yang digunakan [10].

Faktor kepastian (certainty factor) menyatakan kepercayaan dalam sebuah kejadian (fakta atau hipotesa) berdasar bukti atau penilaian pakar. Certainty factor menggunakan suatu nilai untuk mengasumsikan suatu derajat keyakinan seorang pakar terhadap suatu data [11].

$$
\mathrm{CF}[\mathrm{H}, \mathrm{E}]=\mathrm{MB}[\mathrm{H}, \mathrm{E}]-\mathrm{MD}[\mathrm{H}, \mathrm{E}]
$$

Keterangan:

$\mathrm{CF}(\mathrm{H}, \mathrm{E})=$ certainty factor hipotesa yang dipengaruhi oleh evidence e diketahui dengan pasti

$\mathrm{MB}(\mathrm{H}, \mathrm{E})=$ measure of belief terhadap hipotesa $\mathrm{H}$, jika diberikan evidence E (antara 0 dan 1)

$\mathrm{MD}(\mathrm{H}, \mathrm{E})=$ measure of disbelief terhadap evidebce $\mathrm{H}$, jika diberikan evidance E (antara 0 dan 1)
Certainty factor untuk kaidah premis tunggal:

$$
\mathrm{CF}[\mathrm{H}, \mathrm{E}] 1=\mathrm{CF}[\mathrm{H}] * \mathrm{CF}[\mathrm{E}]
$$

Certainty Factor untuk kaidah dengan kesimpulan yang serupa (similarly concluded rules):

$$
\begin{array}{r}
\mathrm{CF} \text { combineCF}[\mathrm{H}, \mathrm{E}] 1,2=\mathrm{CF}[\mathrm{H}, \mathrm{E}] 1+\mathrm{CF}[\mathrm{H}, \mathrm{E}] 2 *[1- \\
\mathrm{CF}[\mathrm{H}, \mathrm{E}] 1]
\end{array}
$$

\section{METODE PENELITIAN}

Metode yang digunakan dalam penelitian ini adalah seperti pada gambar 1. Penelitian ini diawali dengan identifikasi permasalahan yang adalah uraian dari permasalah dan pendekatan-pendekatan yang dapat diaplikasikan.

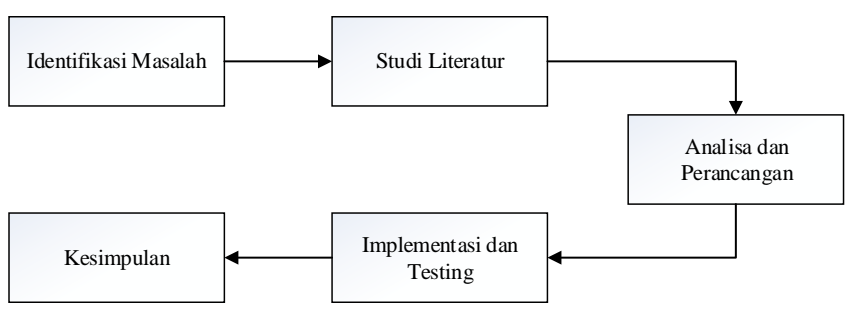

Gambar 1. Tahapan Penelitian

Berdasarkan hasil identifikasi masalah, selanjutnya dilakukan studi literatur yang terkait dengan topik penelitian. Tahap berikutnya adalah analisa dan perancangan aplikasi sistem pakar yang meliputi analisa kebutuhan sistem, perancangan alur sistem, basis data dan user interface. Hasil dari perancangan kemudian diterjemahkan menjadi sebuah aplikasi sistem pakar. Untuk menguji validitas dari output yang diberikan oleh sistem pakar maka pada tahap implementasi juga dilakukan testing pada aplikasi. Tahap terakhir adalah penarikan kesimpulan.

\section{ANALISA DAN PERANCANGAN}

\section{A. Analisa Kebutuhan}

Proses ini dilakukan untuk menentukan kebutuhankebutuhan dalam perancangan aplikasi sistem pakar. Analisa dilakukan dengan melibatkan Prof. Dr. Herdiman T.P. DTM\&H. Sp.PD-KPTI selaku pakar dalam bidang penyakit dalam untuk mendapatkan informasi mengenai macammacam gejala penyakit serta jenis penyakit yang merupakan basis pengetahuan dalam perancangan system pakar. Selain analisa kebutuhan, analisa metode certainty factor yang akan menjelaskan secara rinci tentang metode itu sendiri, dimulai dari penentuan jenis penyakit dan gejala-gejala penyakit tuberkulosis yang telah diberi bobot atau nilai CF dan telah dikonfirmasi oleh pakar.

\section{1) Data Jenis Penyakit Tuberkulosis}

Data jenis penyakit tuberkulosis yang akan digunakan sebagai data pengetahuan yaitu tuberkulosis paru dan tuberkulosis kelenjar.

\section{2) Data Gejala Penyakit Tuberkulosis}

Tabel 1 merupakan daftar data gejala penyakit, data ini sudah berisikan bobot nilai yang akan digunakan dalam perhitungan pada metode certainty factor yang telah melalui proses wawancara dengan pakar. 
Tabel 1. Data gejala penyakit tuberkulosis

\begin{tabular}{|c|c|c|}
\hline Kode & Nama Gejala & Nilai CF Pakar \\
\hline GT001 & Batuk terus menerus selama $\geq 2$ minggu & 1 \\
\hline GT002 & Batuk dengan dahak cair & 0.4 \\
\hline GT003 & Batuk dengan dahak berwarna hijau & 0.5 \\
\hline GT004 & Batuk dengan dahak darah & 0.8 \\
\hline GT005 & Sesak nafas & 0.6 \\
\hline GT006 & Nyeri dada & 0.6 \\
\hline GT007 & Penurunan nafsu makan & 0.4 \\
\hline GT008 & Penurunan berat badan & 0.4 \\
\hline GT009 & Perasaan kurang enak badan/malaise & 0.5 \\
\hline GT010 & $\begin{array}{c}\text { Berkeringat malam hari tanpa ada } \\
\text { kegiatan fisik }\end{array}$ & 0.6 \\
\hline GT011 & Demam & 0.4 \\
\hline GT012 & Demam meriang berkepanjangan & 0.5 \\
\hline GT013 & Menggigil & 0.6 \\
\hline GT014 & $\begin{array}{c}\text { Munculnya benjolan pada bagian yang } \\
\text { mengalami gangguan seperti leher, } \\
\text { ketiak, maupun daerah selangkangan }\end{array}$ & 1 \\
\hline GT015 & $\begin{array}{c}\text { Benjolan terus tumbuh baik ukuran } \\
\text { maupun jumlahnya }\end{array}$ & 0.7 \\
\hline GT016 & \begin{tabular}{c} 
Benjolan terasa kenyal ketika disentuh \\
\hline
\end{tabular} & 0.6 \\
\hline
\end{tabular}

\section{3) Data Nilai Kepastian User}

Tabel 2 merupakan daftar pilihan jawaban dari user beserta nilai bobot yang nantinya pada aplikasi akan ditampilkan ketika user memilih jawaban yang sesuai dengan gejala yang mereka alami.

Tabel 2. Data jawaban user

\begin{tabular}{|c|c|}
\hline Keterangan & Nilai $\boldsymbol{C F}$ User \\
\hline Tidak & 0 \\
\hline Tidak Tahu & 0.1 \\
\hline Mungkin & 0.4 \\
\hline Sedikit Yakin & 0.7 \\
\hline Hampir Yakin & 0.8 \\
\hline Sangat Yakin & 1 \\
\hline
\end{tabular}

4) Data hubungan gejala dengan penyakit

Berikut ini merupakan data relasi hubungan antara gejala penyakit tuberkulosis dengan jenis penyakit tuberkulosis, akan diberi tanda " $x$ " yang menunjukan hubungan antara gejala dan jenis penyakit tuberkulosis.

Tabel 3. Data Hubungan Gejala dan Jenis Penyakit

\begin{tabular}{|c|c|c|}
\hline \multirow{2}{*}{ Kode Gejala } & \multicolumn{2}{|c|}{ Jenis Penyakit } \\
\cline { 2 - 3 } & TB Paru & TB Kelenjar \\
\hline GT001 & $\mathrm{x}$ & \\
\hline GT002 & $\mathrm{x}$ & \\
\hline GT003 & $\mathrm{x}$ & \\
\hline GT004 & $\mathrm{x}$ & \\
\hline GT005 & $\mathrm{x}$ & $\mathrm{x}$ \\
\hline GT006 & $\mathrm{x}$ & $\mathrm{x}$ \\
\hline GT007 & $\mathrm{x}$ & $\mathrm{x}$ \\
\hline GT008 & $\mathrm{x}$ & $\mathrm{x}$ \\
\hline GT009 & $\mathrm{x}$ & $\mathrm{x}$ \\
\hline GT010 & $\mathrm{x}$ & $\mathrm{x}$ \\
\hline GT011 & & $\mathrm{x}$ \\
\hline GT012 & & $\mathrm{x}$ \\
\hline GT013 & & $\mathrm{x}$ \\
\hline GT014 & & \\
\hline GT015 & & \\
\hline GT016 & & \\
\hline & & \\
\hline
\end{tabular}

Berikut ini merupakan aturan-aturan dasar yang merupakan bagian dari penerapan metode certainty factor:

Rule 1: IF GT001 AND GT002 AND GT003 AND GT004 AND GT005 AND GT006 AND GT007 AND GT008 AND GT009 AND GT010 AND GT011 THEN Tuberkulosis Paru

Rule 2: IF GT007 AND GT008 AND GT009 AND GT011 AND GT012 AND GT013 AND GT014 AND GT015 AND GT016 THEN Tuberkulosis Kelenjar

\section{6) Perhitungan Metode Certainty Factor}

Setelah semua data diperoleh, dari mulai jenis penyakit, gejala beserta bobotnya dan nilai jawaban user beserta nilai kepastiannya, maka selanjutnya dilakukan perhitungan nilai certainty factor berdasarkan setiap gejala untuk masing-masing penyakit dengan cara mengalikan nilai kepastian gejala dari pakar dengan nilai kepastian dari user. Berikut adalah rumus awal perhitungan metode certainty factor:

$$
\begin{array}{r}
\mathrm{CF}[\mathrm{H}, \mathrm{E}]_{\mathrm{n}}=\mathrm{CF}[\mathrm{H}]_{\mathrm{n}} * \mathrm{CF}[\mathrm{E}]_{\mathrm{n}} \\
=\mathrm{CF} \text { pakar } * \mathrm{CF} \text { user } \\
=\text { hasil }_{\mathrm{n}}
\end{array}
$$

Keterangan:

$$
\mathrm{n} \text { : Jumlah gejala }
$$

\section{B. Perancangan}

Tahap perancangan berisikan rancangan umum terkait aplikasi system pakar yang akan dikembangkan. Hal itu meliputi flowcharts, use case dan entity relationship diagram (ERD).

\section{1) Flowcharts}

Flowchart pada gambar 2 menggambarkan alur pada aplikasi. Proses diawali pilihan bagi user untuk melakukan registrasi untuk login. Halaman beranda akan muncul apabila user berhasil login. Selanjutnya pada halaman beranda tersedia empat pilihan yang dapat dipilih, yakni artikel informasi, diagnosa, rekam medik dan logout.

\section{5) Rules Based}




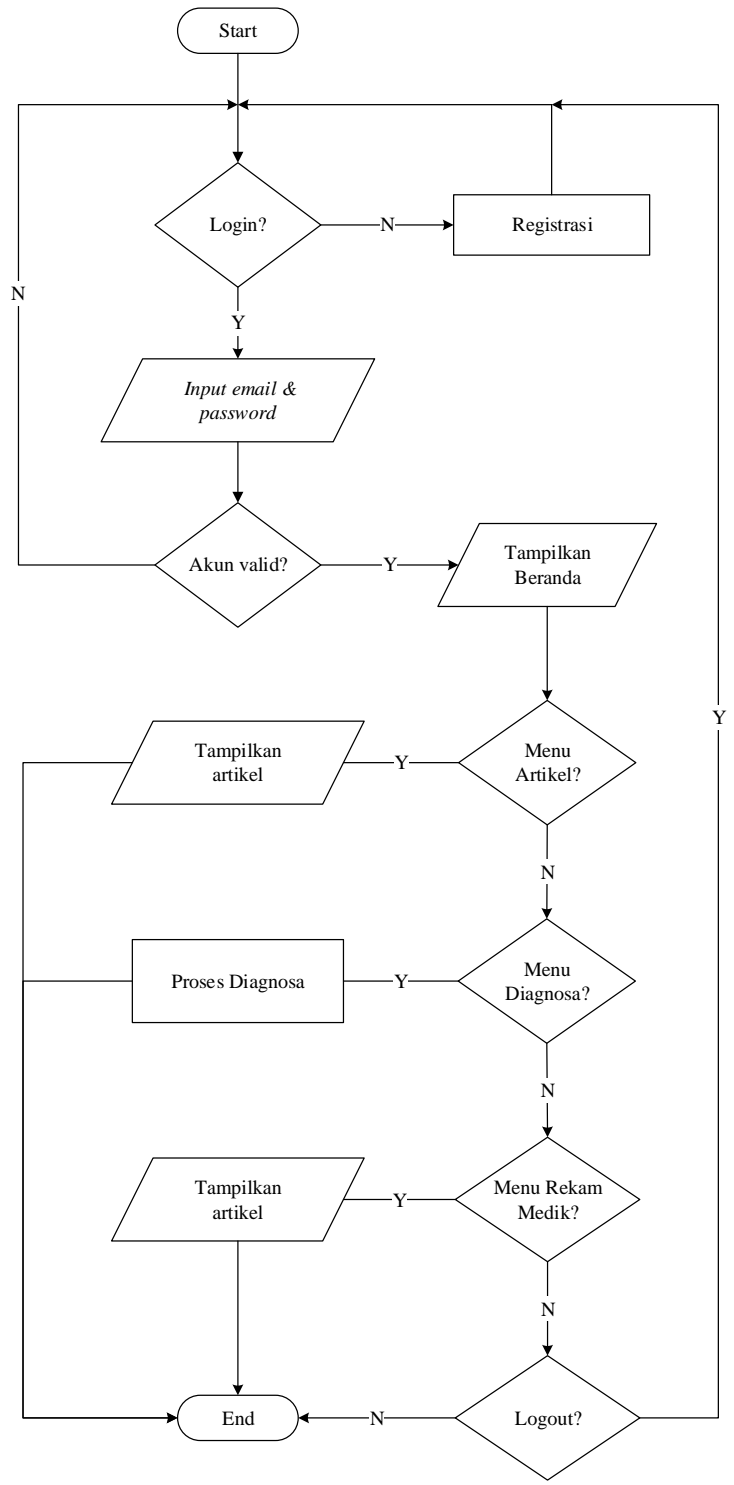

Gambar 2. Alur sistem aplikasi Sistem Pakar Diagnosa

Sistem pakar dengan metode certainty factor akan diimplementasikan pada menu diagnosa. Flowchart dari proses pendiagnosaan adalah seperti pada gambar 3 .

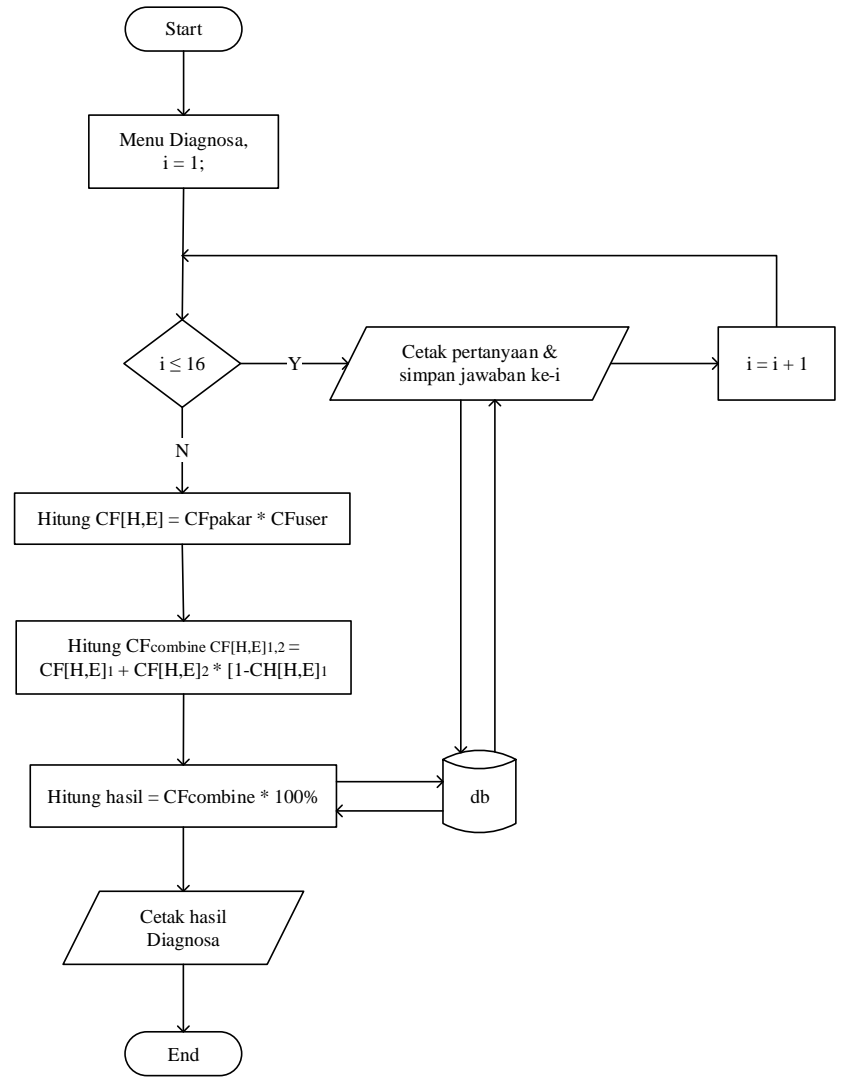

Gambar 3. Flowchart proses diagnosa penyakit

\section{2) Use Case Diagram}

Gambar 4 merupakan use case diagram dari system yang dirancang. Di sini user dapat melakukan aktivitas seperti melakukan registrasi akun (register), melakukan proses login \& logout, membaca artikel informasi, melakukan diagnosa penyakit hingga melihat rekam medik dari akun yang bersangkutan.

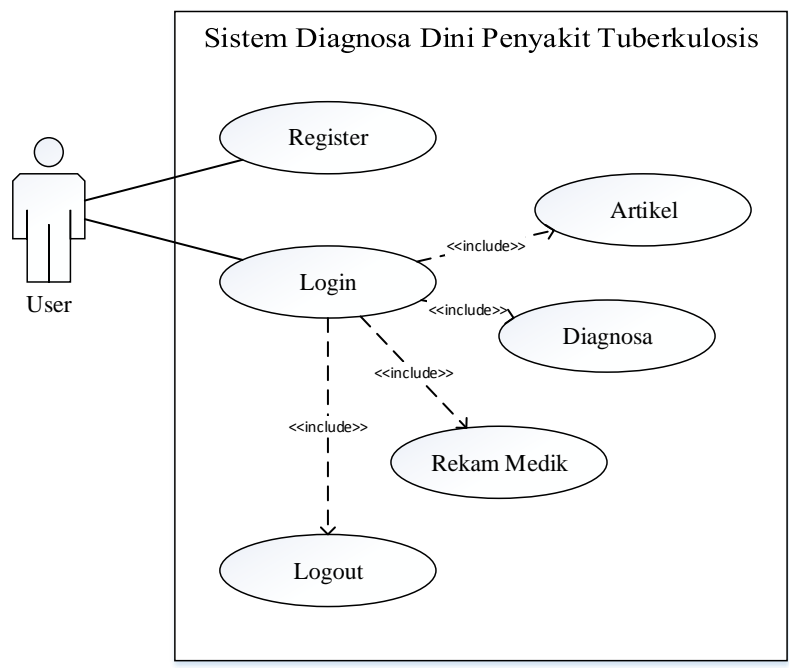

Gambar 4. Use Case Diagram 


\section{3) Entity Relationship Diagram}

Tahap ini menjelaskan tahap perancangan database yang dapat dijelaskan melalui relasi antar entitas. Terdapat lima entitas yang saling berhubungan, entitas user memiliki hubungan one to many dengan entitas record dikarenakan satu user dapat memiliki banyak record. Entitas record memiliki hubungan many to many dengan entitas history dikarenakan banyak record dapat memiliki lebih dari satu history. Entitas history memiliki hubungan one to many dengan entitas penyakit dikarenakan satu history memiliki lebih dari satu penyakit. Entitas penyakit memiliki hubungan one to many dengan entitas gejala dikarenakan satu penyakit memiliki lebih dari satu gejala. Berikut ini adalah gambaran hubungan antar entitas yang dapat dilihat pada Gambar 5.

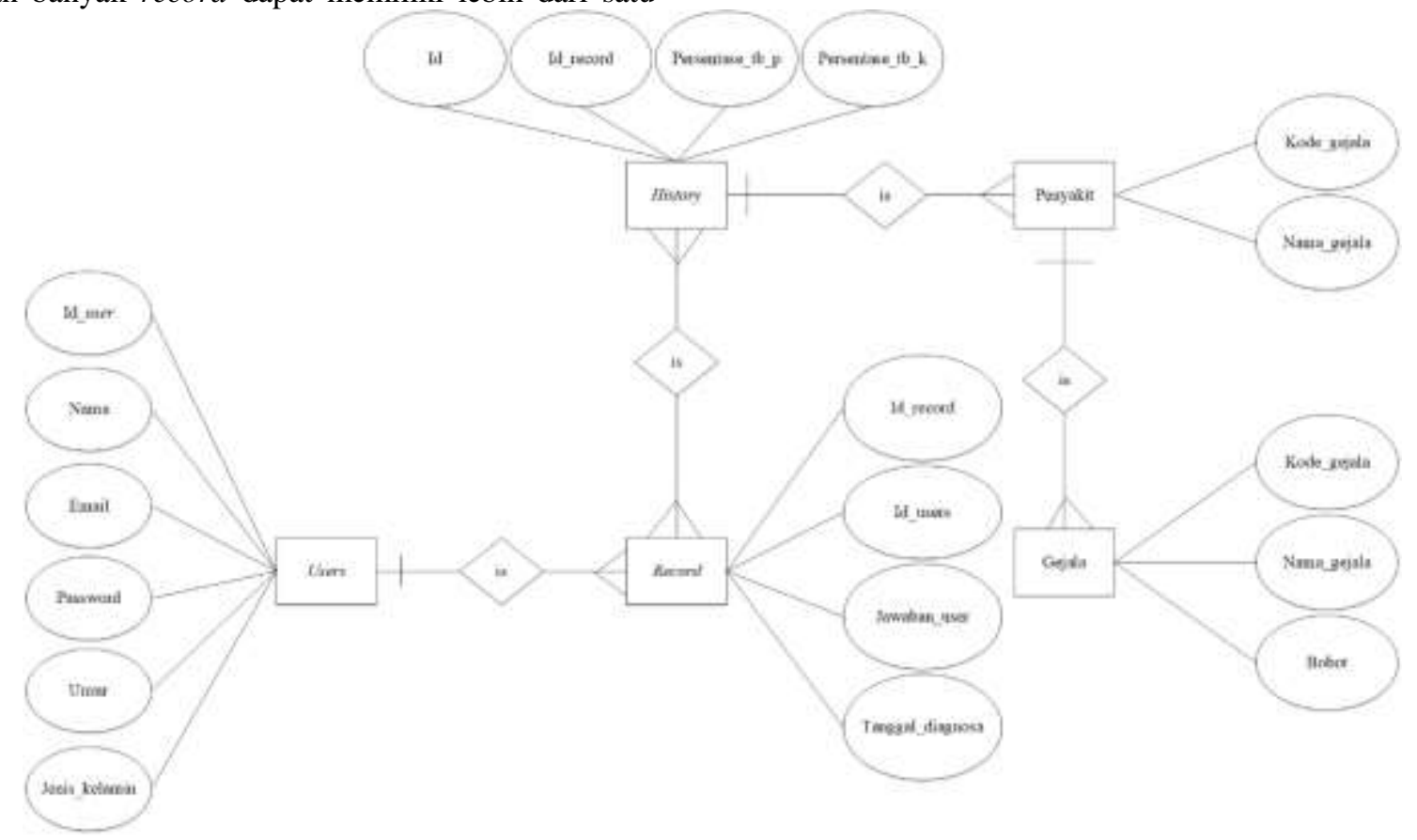

Gambar 5. Entity Relationship Diagram

\section{IMPLEMENTASI DAN EVALUASI}

\section{A. Implementasi}

Setelah tahap perancangan selesai dilakukan maka tahap selanjutnya adalah tahap implementasi. Berikut ini adalah hasil dari implementasi aplikasi mobile sistem pakar diagnosa dini penyakit tuberkulosis menggunakan metode certainty factor berbasis android.

Gambar 6 merupakan tampilan halaman login yang akan muncul pertama kali saat aplikasi dijalankan. Di sini user yang telah memiliki akun harus melakukan proses login terlebih dahulu agar dapat masuk ke dalam halaman beranda. Menu registrasi disediakan untuk user yang baru pertama kali dan dimaksudkan untuk keperluan pendaftaran akun.
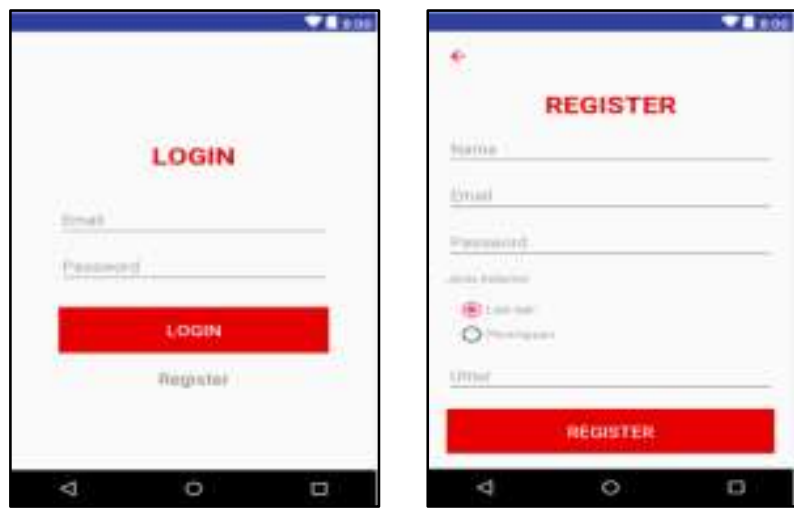

Gambar 6. Halaman login dan register
Halaman seperti pada gambar 7 akan ditampilkan apabila user berhasil login. Di sini user dapat melakukan berbagai kegiatan seperti melihat informasi seputar penyakit tuberkulosis, melakukan diagnosa penyakit, serta melihat riwayat diagnosa yang pernah dilakukan melalui menu rekam medik.

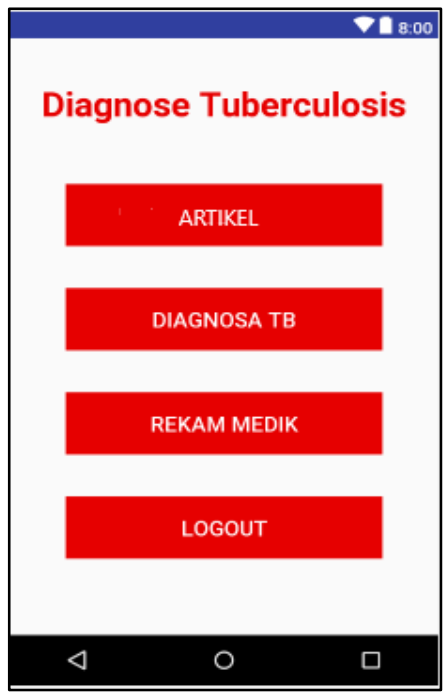

Gambar 7. Halaman Beranda

Gambar 8.a merupakan tampilan dari halaman diagnosa penyakit yang diberisikan pertanyaan serta pilihan jawaban 
yang nanti akan dijawab oleh user. Di sini user diminta untuk memilih jawaban sesuai dengan tingkat keyakinan user. Sesuai perancangan maka terdapat 16 pertanyaan dan 6 pilihan jawaban dengan nilai CF seperti yang telah ditetapkan sebelumnya.

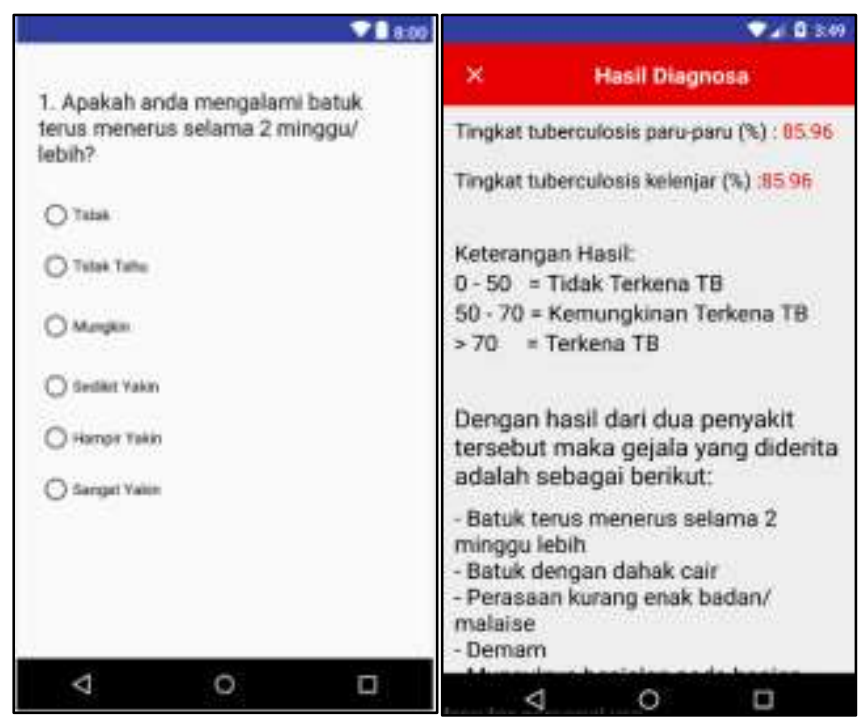

Gambar 8. Halaman Diagnosa Penyakit

Gambar 8.b merupakan tampilan dari halaman hasil diagnosa penyakit yang akan ditampilkan diakhir proses diagnosa. Hasilnya berupa nilai persentase dari dua jenis penyakit tuberkulosis beserta rekapan gejala yang dialami oleh user.

Gambar 9 merupakan tampilan dari halaman rekam medik yang berisikan riwayat hasil diagnosa yang pernah dilakukan oleh user beserta tanggal diagnosa dilakukan.

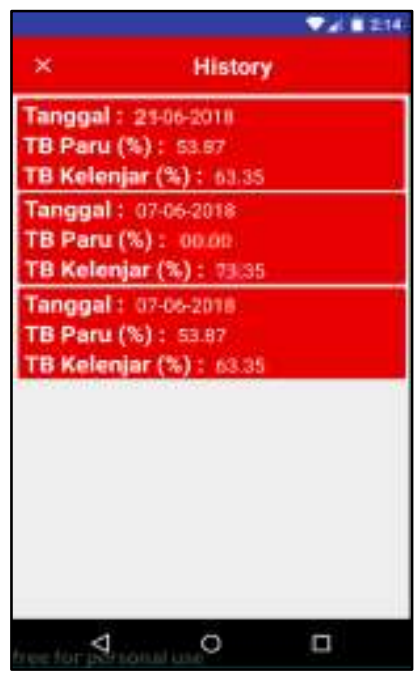

Gambar 9. Halaman Rekam Medik

\section{B. Evaluasi}

Evaluasi berupa testing pada aplikasi dilakukan dengan menggunakan pendekatan white box testing dan black box testing. Pengujian white box yang diuji berupa validitas hasil perhitungan sistem dibandingkan dengan hasil perhitungan yang dilakukan dengan menggunakan excel. Sedangkan pengujian black box dilakukan dengan cara menguji keberhasilan dari beberapa fungsi yang terdapat pada aplikasi seperti fungsi dari login, register, diagnosa penyakit, hasil diagnosa, dan rekam medik.

Setelah pengujian dilakukan kemudian hasil dari aplikasi akan dibandingkan dengan keputusan pakar, pakar disini adalah Prof. Dr. Herdiman T.P. DTM\&H. Sp.PDKPTI. Perbandingan akan dilakukan dengan menggunakan 5 data yang telah didapatkan pada saat aplikasi dibuka untuk testing dengan pakar. Data yang diuji dengan pakar adalah seperti pada table 4 .

Tabel 4. Data pengujian

\begin{tabular}{|c|c|c|c|c|}
\hline \multicolumn{5}{|c|}{ Data Pasien } \\
\hline $\mathbf{A}$ & B & $\mathrm{C}$ & D & $\mathbf{E}$ \\
\hline $\begin{array}{l}\text { Hampir } \\
\text { Yakin }\end{array}$ & Tidak & $\begin{array}{l}\text { Sedikit } \\
\text { Yakin }\end{array}$ & Tidak & $\begin{array}{c}\text { Hampir } \\
\text { Yakin }\end{array}$ \\
\hline Tidak & Tidak & Tidak & Tidak Tahu & Tidak \\
\hline Tidak & Tidak & Tidak & Mungkin & Tidak \\
\hline $\begin{array}{l}\text { Sedikit } \\
\text { Yakin }\end{array}$ & Tidak & Mungkin & $\begin{array}{l}\text { Sedikit } \\
\text { Yakin }\end{array}$ & Tidak \\
\hline Tidak & Tidak & Tidak & Tidak & Tidak \\
\hline Tidak & Tidak & Tidak & Tidak Tahu & Tidak \\
\hline Mungkin & Mungkin & Mungkin & $\begin{array}{l}\text { Sangat } \\
\text { Yakin }\end{array}$ & Mungkin \\
\hline Mungkin & Tidak Tahu & Mungkin & Mungkin & Tidak Tahu \\
\hline $\begin{array}{l}\text { Sedikit } \\
\text { Yakin }\end{array}$ & $\begin{array}{l}\text { Sedikit } \\
\text { Yakin }\end{array}$ & $\begin{array}{l}\text { Sedikit } \\
\text { Yakin }\end{array}$ & $\begin{array}{c}\text { Sedikit } \\
\text { Yakin }\end{array}$ & $\begin{array}{c}\text { Sedikit } \\
\text { Yakin }\end{array}$ \\
\hline Tidak & Tidak & Mungkin & $\begin{array}{l}\text { Sangat } \\
\text { Yakin }\end{array}$ & Tidak \\
\hline Tidak & Mungkin & Tidak & Tidak & Tidak \\
\hline Tidak & Tidak Tahu & Tidak & Tidak & Tidak \\
\hline Tidak & Mungkin & Tidak & Tidak & Tidak \\
\hline Tidak & $\begin{array}{c}\text { Hampir } \\
\text { Yakin }\end{array}$ & $\begin{array}{l}\text { Sedikit } \\
\text { Yakin }\end{array}$ & Tidak & Tidak \\
\hline Tidak & $\begin{array}{l}\text { Sedikit } \\
\text { Yakin }\end{array}$ & Mungkin & Mungkin & Tidak \\
\hline Tidak & $\begin{array}{l}\text { Hampir } \\
\text { Yakin }\end{array}$ & Mungkin & $\begin{array}{l}\text { Hampir } \\
\text { Yakin }\end{array}$ & Tidak \\
\hline
\end{tabular}

Tabel 5. Nilai hasil pengujian

\begin{tabular}{|c|c|c|}
\hline $\begin{array}{c}\text { Jenis Penyakit / } \\
\text { Pasien }\end{array}$ & $\begin{array}{c}\text { Tuberkulosis } \\
\text { Paru }\end{array}$ & $\begin{array}{c}\text { Tuberkulosis } \\
\text { Kelenjar }\end{array}$ \\
\hline A & 95.96 & 54.14 \\
\hline B & 55.97 & 98.31 \\
\hline C & 92.89 & 92.47 \\
\hline D & 95.84 & 87.73 \\
\hline E & $\mathbf{8 9 . 5 2}$ & $\mathbf{4 7 . 5 8}$ \\
\hline
\end{tabular}

Dari lima hasil pengujian terdapat satu hasil yang dianggap tidak valid oleh pakar yaitu hasil milik pasien E. Menurut pakar hasil tersebut dianggap tidak valid karena jawaban dari pasien ketika melakukan diagnosa melalui aplikasi terbilang masih kurang mendukung terhadap nilai kepastian dari hasil diagnosa. Karena dengan tingkat nilai yang dihasilkan oleh aplikasi ketika pasien E melakukan diagnosa tidak sesuai dengan jawaban apabila seorang pasien terkena sebuah penyakit tuberkulosis. Untuk menghitung error dari hasil pengujian maka digunakan rumus Tingkat error $=\frac{\text { Jumlah data yang tidak valid }}{\text { Seluruh data yang ada }} \quad$ sehingga tingkat error yang didapat adalah sebesar $20 \%$ yang dapat dikategorikan memiliki tingkat kesalahan yang rendah. 


\section{KESIMPULAN}

Kesimpulan dari hasil penelitian ini adalah bahwa metode certainty factor dapat digunakan untuk mengembangkan sebuah aplikasi sistem pakar yang digunakan untuk mendiagnosa penyakit tuberkulosis paru dan tuberkulosis kelenjar dengan tingkat kesalahan yang rendah.

\section{REFERENSI}

[1]. Leony Lidya. 2017. Developing Expert System for Tuberculosis Diagnose to Support Knowledge Sharing in the Era of National Health Insurance System. IOP Conference Series: Materials Science and Engineering. United Kingdom: Annual Applied Science and Enggineering Conference.

[2]. Global Tuberculosis Report 2017. World Health Organization. 2017.

[3]. Profil Kesehatan Indonesia. Kemenkes RI. 2016.

[4]. Mudiyono, Nur Endah W dan M Sakundarno Adi. 2015. Relationship Between Mother's Behavior and Physical Environment House of Children with Incidence of Pulmonary Tuberculosis In Pekalongan City. Jurnal Kesehatan Lingkungan Indonesia Vol. 14 No.2

[5]. Pardjono, Puguh Santoso, Dyah Ika Krisnawati, Erna Susilowati, Elfi Quyumi dan Novita Setyowati. 2012. Pengaruh Dinamika Kelompok Sosial Terhadap Angka Kejadian Dan Penyembuhan Penyakit Tuberkulosis Paru Di Wilayah Puskesmas Mojoroto. Jurnal Ilmu Kesehatan Vol. 1 No. 1.

[6]. Nur Aini, Ramadiani dan Heliza Rahmania Hatta. 2017. Sistem Pakar Pendiagnosa Penyakit Tuberculosis. Jurnal Informatika Mulawarman Vol. 12 No. 1

[7]. Rahmi Ras Fanny, Nelly Astuti Hasibuan dan Efori Buulolo. 2017. Perancangan Sistem Pakar Diagnosa Penyakit Asidosis Tubulus Renalis Menggunakan Metode Certainty Factor Dengan Penulusuran Forward Chaining. Media Informatika Budidarma Vol. 1 No. 1.

[8]. InfoDatin Pusat Data dan Informasi Kementrian Kesehatan RI. Tuberkulosis Temukan Obati Sampai Sembuh. Kemenkes RI. 2016.

[9]. Hartatik. 2015. Diagnosa Jenis Tuberculosis Dengan Algoritma Bayes. Konferensi Nasional Sistem \& Informatika. STMIK STIKOM Bali

[10]. Whisnu Ulinnuha Setiabudi, Endang Sugiharti dan Florentina Yumi Arini. 2017. Expert System Diagnosis Dental Disease Using Certainty Factor Method. Scientific Journal of Informatics Vol. 4 No. 1

[11]. Nur Anjas Sari. 2013. Sistem Pakar Mendiagnosa Penyakit Demam Berdarah Menggunakan Metode Certainty Factor. Pelita Informatika Budi Darma Vol.4 No. 3 